
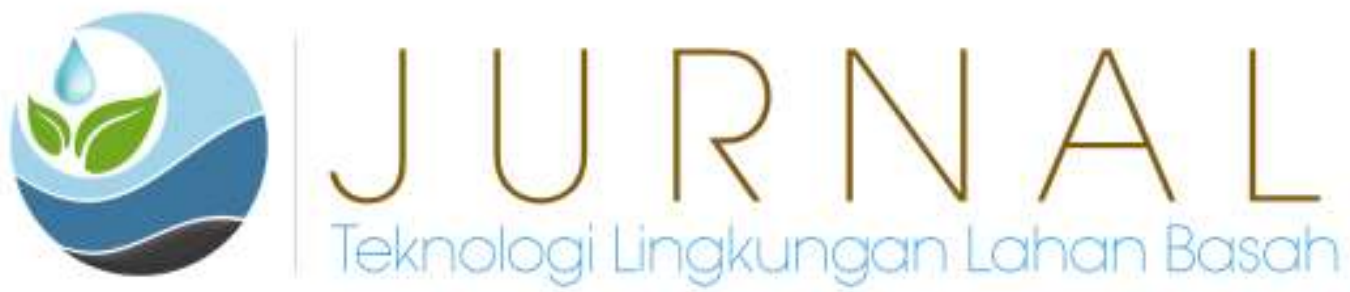

\title{
Pengaruh Penambahan Lumpur PDAM dan Zeolit sebagai Media Imobilisasi Bakteri terhadap Produksi Biogas dari Limbah Organik Pasar (Effect of Addition PDAM Sludge and Zeolite as Bacterial Immobilization Media on Biogas Production from Organic Waste)
}

\author{
Wivina Diah Ivontianti ${ }^{1}$, Rinjani Ratih Rakasiwi ${ }^{1}$, dan Dwi Asniawati ${ }^{1}$ \\ Jurusan Teknik Kimia Universitas Tanjungpura \\ E-mail : wivinadiahivontianti@untan.ac.id
}

\begin{abstract}
Organic waste can be processed into biogas through the anaerobic decomposition process. Anaerobic decomposition can be influenced by various factors including the addition of immobilization media. Cell immobilization is an attempt to increase the stability of the anaerobic process while reducing the potential for washout. Adding this solid material can increase reactor efficiency and can increase methane yield. The research on the addition of zeolite and PDAM sludge as immobilization media aims to find out how the effect of the addition of immobilized media, as well as the best composition between PDAM slurry and zeolite as immobilization media in the biogas production process from organic waste. The immobilization media used has three variations in the composition ratio between PDAM sludge and zeolites, namely 2:0, 2:1, 1:1 and a control reactor. Observation parameter are of VS, pH, concentration of methane gas and gas volume. Based on observations made, it was known that the addition of zeolite and sludge PDAM as a medium of immobilization in the biogas production process could increase biogas production and the concentration of methane produced. Of the three variations in the composition of the media used in this study, the composition ratio of 2: 1 gave the best biogas production results in the amount of $23.2844 \mathrm{~L}$. As for the methane concentration, the overall reactor with the addition of immobilization media results in higher biogas concentrations and the reactor with the addition of media with a ratio of 2: 1 gave the largest methane concentration results.
\end{abstract}

Keywords: biogas, immobilization, PDAM Sludge, zeolite

\begin{abstract}
Abstrak
Sampah organik pasar dapat diolah menjadi biogas melalui proses penguraian anaerobik. Penguraian anaerobik ini dapat dipengaruhi oleh berbagai faktor diantaranya penambahan media imobilisasi. Imobilisasi sel adalah salah satu usaha untuk meningkatkan stabilitas proses anaerob sekaligus mengurangi potensi washout. Penambahan material padatan ini dapat meningkatkan efisiensi reaktor dan dapat meningkatkan yield metana. Penelitian bertujuan untuk mengetahui bagaimana pengaruh penambahan media imobilisasi tersebut, serta komposisi terbaik antara lumpur limbah PDAM dan zeolit sebagai media imobilisasi pada proses produksi biogas dari limbah pasar. Media imobilisasi yang digunakan memiliki tiga variasi perbandingan komposisi antara lumpur PDAM dan zeolit, yaitu 2:0, 2:1, 1:1 dan reaktor kontrol. Parameter pengamatan adalah nilai VS, pH, konsentrasi gas metana, dan volume gas. Berdasarkan hasil pengamatan yang dilakukan diketahui bahwa penambahan zeolit dan lumpur PDAM sebagai media imobilisasi pada proses produksi biogas dapat meningkatkan produksi biogas serta konsentrasi metana yang dihasilkan. Dari tiga variasi perbandingan komposisi media yang digunakan dalam penelitian ini, perbandingan komposisi 2:1 memberikan hasil produksi biogas terbaik yaitu sebesar 23,2844 L. Sedangkan untuk konsentrasi metana, reaktor dengan penambahan media imobilisasi menghasilkan konsentrasi biogas yang lebih tinggi dengan hasil terbaik yaitu variasi perbandingan 2:1.
\end{abstract}

Kata kunci: biogas, immobilisasi, lumpur PDAM, zeolit 


\section{PENDAHULUAN}

Sampah pasar merupakan limbah padat salah satunya berupa bahan organik yang dihasilkan dari kegiatan di pasar yang berupa sisa sayur dan buah serta sisa pemotongan hewan . Limbah organik pasar ini telah menjadi permasalahan di setiap kota-kota besar yang dapat diakibatkan kurangnya pengolahan serta pemanfaatan sampah tersebut sehingga menyebabkan terjadinya penumpukan sampah di Tempat Pemrosesan Akhir (TPA). Salah satu langkah yang dapat dilakukan untuk mengolah sampah pasar adalah dengan memanfaatkannya sebagai bahan baku pembuatan biogas. Telah diketahui bahwa sampah pasar mengandung limbah organik sehingga layak untuk dijadikan bahan baku pada pembuatan biogas. Pembuatan biogas dilakukan dengan proses penguraian secara anaerobik yang merupakan dekomposisi oleh mikroorganisme dalam kondisi tanpa oksigen. Proses peruraian anaerobik terdiri dari 3 tahapan proses yang melibatkan beberapa kelompok bakteri berbeda yaitu: tahap peruraian atau hidrolisis, tahap asidogenesis, dan tahap metanogenesis (Ziemiński dan Frąc, 2012).

Namun di sisi lain, pertumbuhan bakteri anaerob yang berjalan lambat menyebabkan degradasi anaerobik memerlukan waktu yang lebih lama. Selain itu, pada laju alir yang tinggi dapat menyebabkan mikroorganisme terbawa keluar bersama aliran limbah (washout) Salah satu langkah yang dapat dilakukan untuk menangani permasalahan yang terjadi pada penguraian anaerobik adalah dengan menambahkan media imobilisasi. Prinsip dari imobilisasi sel adalah mengikat sel bakteri di dalam suatu media atau menambahkan material padatan ke dalam reaktor anaerob sebagai media melekatnya bakteri. Media imobilisasi akan membatasi gerak bakteri, dengan demikian bakteri akan saling berdekatan dan menghindari terjadinya wash out, yaitu populasi bakteri terbawa keluar bersama outlet reaktor. Hal ini dapat mempercepat pertumbuhan bakteri yang memiliki laju pertumbuhan lambat. Pertumbuhan bakteri yang lebih cepat menyebabkan konsentrasi sel di dalam reaktor meningkat sehingga memperpendek waktu proses peruraian (Mellyanawati, 2017).

Pada penelitian ini, substrat atau bahan baku utama yang digunakan adalah limbah pasar yang didapat dari pasar Flamboyan Pontianak. Sedangkan yang berperan sebagai media imobilisasi adalah zeolit dan limbah lumpur dari Perusahaan Daerah Air Minum (PDAM) Tirta Khatulistiwa Kota Pontianak. Lumpur PDAM juga diketahui memiliki karakteristik yang mendekati karakteristik zeolit A standar. Sintesis zeolit A menggunakan lumpur PDAM Kota Pontianak dengan kandungan $\mathrm{SiO}_{2}: \mathrm{Al}_{2} \mathrm{O}_{3}$ sebesar 49,11\% : 29,45\% dihasilkan zeolit yang mendekati karakteristik zeolit A standar yang teridentifikasi dengan karakterisasi XRD pada puncak $2 \theta$ karakteristik zeolit A standar, yaitu pada zeolit hasil penelitian ini memiliki puncak $2 \theta=12,43 ; 27,94$ dan 34,63 dengan nilai kapasitas tukar kation sebesar 128,080 cmol+/kg dan daya serap terhadap iod sebesar 593,875 mg/g (Hajar, 2014). Lumpur PDAM memiliki kandungan mineralmineral yang dapat menjadi sumber makanan bagi bakteri pada proses pembuatan biogas. Dengan demikian diharapkan penambahan lumpur PDAM sebagai media imobilisasi pada proses pembuatan biogas dapat memberikan dampak positif seperti meningkatkan nilai efektifitas proses

Selain itu zeolit merupakan bahan penyerap (adsorben) yang sangat baik karena memiliki banyak pori, serta luas permukaan yang cukup tinggi. Zeolit dapat digunakan sebagai media imobilisasi karena merupakan bahan penjerap (adsorben) dengan kemampuan tinggi karena sifatnya memiliki banyak pori dan luas permukaan yang cukup tinggi serta kemampuan tukar kation yang baik. Sifat ini dapat dimanfaatkan untuk menyimpan kation-kation yang disukai mikroorganisme di dalam zeolit (Mellyanawaty, 2017).

Pemilihan limbah lumpur PDAM sebagai media imobilisasi karena pada dasarnya limbah lumpur PDAM belum dimanfaatkan secara maksimal. Selain itu, 
limbah lumpur PDAM mengandung banyak mineral serta logam-logam yang dapat berperan sebagai mikronutrien bagi bakteri anaerobik (Halim, 2015). Dengan demikian, penambahan media imobilisasi berupa zeolit dan lumpur limbah PDAM diharapkan dapat mempercepat proses pertumbuhan bakteri anaerobik dan dapat mencegah terjadinya washout, sehingga dapat mengoptimumkan proses pembentukan biogas.

\section{METODE PENELITIAN}

Pada penelitian ini akan dilakukan pembuatan media imobilisasi dari lumpur PDAM dan Zeolit. Kemudian dilakukan pengolahan limbah organik pasar melalui degradasi anaerobik menggunakan reaktor Batch.

\section{Pembuatan Media Imobilisasi}

Lumpur PDAM yang telah dibersihkan dari pengotor dikeringkan dengan bantuan panas matahari selama 3 hari dan dihaluskan. Proses selanjutnya adalah pembuatan campuran antara zeolit dan lumpur PDAM dengan 3 variasi perbandingan berat yaitu 0:1 (media A), 1:1 (media B) dan 1:2 (media C). Campuran tersebut dicampur hingga homogen dan ditambahkan dengan air dan dicetak raschig ring. Media dijemur panas matahari selama 3 hari, lalu dipanaskan pada suhu $60^{\circ} \mathrm{C}$ selama 12 jam menggunakan oven. Kemudian dikalsinasi menggunakan furnace pada suhu $550^{\circ} \mathrm{C}$ selama 1 jam. Dilakukan uji rendam untuk mengetahui ketahanan media.

\section{Proses Pembentukan Biogas}

Substrat yang digunakan adalah campuran antara limbah organik pasar dengan kotoran sapi dengan perbandingan volume 2:1. Kemudian substrat tersebut diencerkan dengan menambahkan air dengan perbandingan 1:1 dari volume substrat. Sedangkan media imobilisasi yang digunakan sebanayak $1 \mathrm{~kg}$, serta digunakan 1 media kontrol tanpa penambahan media imobilisasi. Jadi reaktor yang digunakan pada penelitian ini berjumlah 4 reaktor, dimana pada reaktor 1 digunakan media $\mathrm{A}$, reaktor 2 media $\mathrm{B}$, reaktor 3 media $\mathrm{C}$, dan reaktor 4 tanpa media yang merupakan kontrol. Berikut adalah gambar rangkaian digester batch pada penelitian ini :

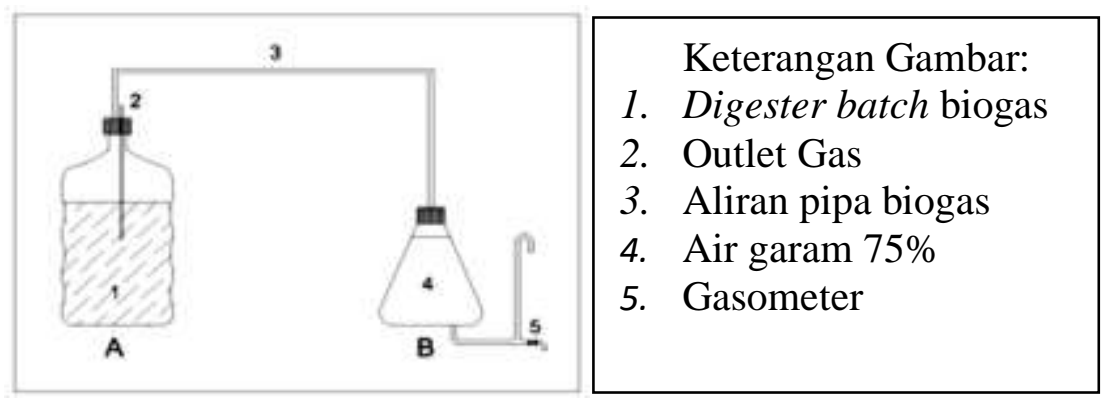

Gambar 1. Rangkaian dan Keterangan Alat

Analisis parameter pengamatan dilakukan dengan pengambilan sampel setiap 3 hari sekali untuk dilakukan pengamatan data nilai $\mathrm{VS}, \mathrm{pH}$, dan konsentrasi gas metana, sedangkan pengukuran volume gas dilakukan setiap hari.

\section{Analisis dan Pengamatan Data Pengukuran}

a. Pengukuran Total Solid (TS) dan Volatile Solid (VS)

Pengukuran Total Solid (TS) dan Volatile Solid (VS) dilakukan setiap 3 hari sekali dan dimulai pada hari ke-7 proses produksi biogas. TS dan VS dapat dihitung dengan metode gravimetric sesuai metode standar SNI 2005.

b. Derajat Keasaman $(\mathrm{pH})$

Derajat keasaman $(\mathrm{pH})$ substrat pada proses produksi biogas diukur menggunakan $\mathrm{pH}$ meter setiap 3 hari sekali. 
c. Volume Biogas

Pengukuran volume biogas dilakukan setiap hari dengan high gasometer yang sebagian terendam air garam $75 \%$ jenuh pada wadah terbuka. Gas mengalir ke kolom melalui katup bawah yang terhubung langsung ke reaktor (Walker dkk, 2009)

d. Konsentrasi Gas Metana $\left(\mathrm{CH}_{4}\right)$

Sampel gas diambil melalui selang penghubung antara reaktor dan gasometer dengan menggunakan high pressure gas syringe, gas tersebut kemudian dimasukkan kedalam venoject tube. Kemudian sampel dianalisis menggunakan Gas Chromatography.

\section{HASIL DAN PEMBAHASAN}

Proses produksi biogas pada penelitian ini dilakukan secara batch dimana pengisian umpan dilakukan hanya sekali diawal proses. Reaktor yang digunakan adalah reaktor batch anaerobik yang terbuat dari galon plastik dengan volume 5 liter, keran yang terdapat pada bagian bawah galon digunakan sebagai outlet atau saluran untuk keluarnya slurry yang akan digunakan pada saat melakukan pengujian sampel.

\section{a. Pengamatan Volatile Solid (VS)}

Nilai Volatile Solid (VS) merupakan parameter yang digunakan untuk merepresentasikan unjuk kerja dari bakteri asidogen (Budianto, 2017). Secara keseluruhan fase hidup bakteri selama 30 hari terjadi penurunan nilai VS yang menandakan bakteri bekerja dengan baik. Kinerja bakteri menunjukan nilai yang berbeda-beda pada tiap reaktor. Pada hari ke-13 pada reaktor control D yang berperan sebagai reaktor kontrol mengalami peningkatan nilai VS, hal tersebut karena pada reaktor ini tidak ditambahkan media sehingga terjadi wash out, dimana bakteri ikut terbawa keluar reaktor pada proses pengambilan sampel dan terbaca sebagai VS.

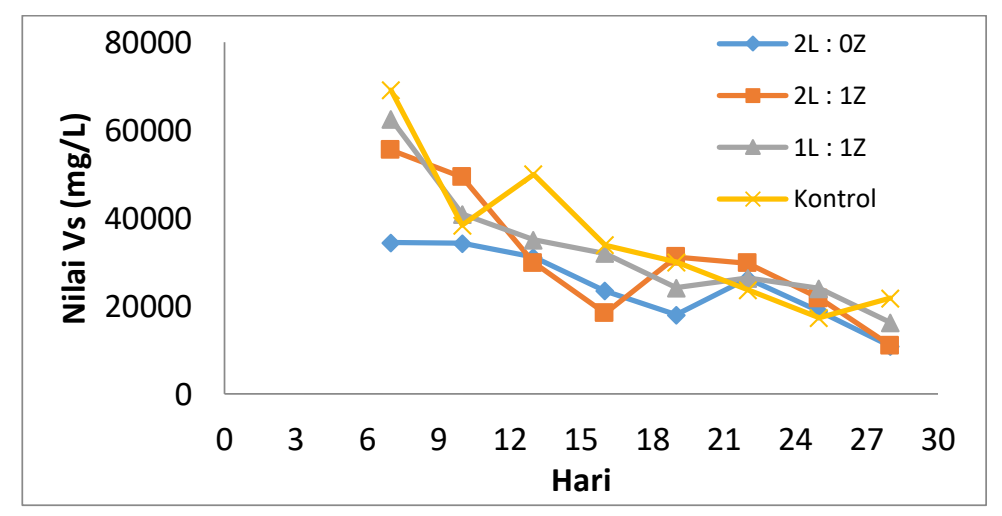

Gambar 2. Grafik Nilai VS

Pada hari ke-16 bakteri telah memasuki fase log terjadi penurunan nilai VS paling besar terjadi pada reaktor B (2Z:1L) yaitu sebesar $37.090 \mathrm{mg} / \mathrm{L}$, reaktor kontrol sebesar $35.240 \mathrm{mg} / \mathrm{L}$, reaktor C (1Z:1L) sebesar $30.850 \mathrm{mg} / \mathrm{L}$ dan reaktor A (0Z:2L) sebesar $11.030 \mathrm{mg} / \mathrm{L}$. Hal tersebut menunjukan bahwa penambahan lumpur PDAM dan zeolit sebagai media imobilisasi memberikan pengaruh yang baik terhadap proses penguraian anaerobik karena didalam lumpur PDAM itu sendiri mengandung logam dan mineral (trace metal) yang dibutuhkan oleh mikroorganisme. Mikroorganisme membutuhkan logam esensial tertentu, khususnya methanogenic archaebacteria diketahui memerlukan $\mathrm{Fe}$, Co, dan Ni. Berdasarkan penelitian yang dilakukan oleh Lasah (2011) kandungan terbesar di dalam lumpur PDAM adalah $\mathrm{Fe}$, dimana $\mathrm{Fe}$ merupakan salah satu trace metal yang dibutuhkan mikroorganisme. Oleh karena itu, penambahan lumpur PDAM memberikan pengaruh positif berupa penurunan nilai VS terutama pada penambahan dengan perbandingan komposisi antar lumpur PDAM dan 
zeolit sebesar (2:1). Sedangkan pada penambahan media yang hanya berupa lumpur PDAM saja penurunan nilai VS cenderung lebih rendah daripada reaktor lainnya, hal tersebut dapat terjadi karena trace metal yang terkandung di dalam media tersebut terlalu tinggi yang justru menjadi racun bagi mikroorganisme. Sehingga menyebabkan mikroorganisme mati dan akan terbaca sebagai VS. Kandungan $\mathrm{Fe}$ pada proses fermentasi yang cukup tinggi dapat menjadi racun bagi proses metabolisme mikroba dan menyebabkan perombakan kandungan organik pada limbah berkurang (Suraya, 2012).

Hingga pada hari ke-22 bakteri telah memasuki death phase atau fase kematian dan dengan asumsi bahwa pada hari ke-0 besarnya nilai TS dan VS pada masing-masing reaktor sama, maka dapat dilihat bahwa nilai VS pada reaktor B yang ditambahkan media dengan perbandingan antara lumpur dan zeolit sebesar 2:1 mengalami penurunan nilai VS yang cenderung lebih besar daripada reaktor lainnya, hal tersebut menunjukan bahwa pada reaktor B kinerja bakteri lebih baik sehingga bahan organik dapat terdedgaradasi lebih besar yang ditandai dengan penurunan nilai VS. Oleh karena itu dapat ditarik kesimpulan bahwa penambahan lumpur PDAM sebagai media imobilisasi memberikan pengaruh yang baik bagi penurunan nilai VS.

\section{b. Pengamatan Derajat Keasaman (pH)}

Pada penelitian ini dilakukan pengamatan mengenai besarnya nilai derajat keasaman atau $\mathrm{pH}$, adapun hasil pengamatan tersebut dapat dilihat pada Gambar 3 :

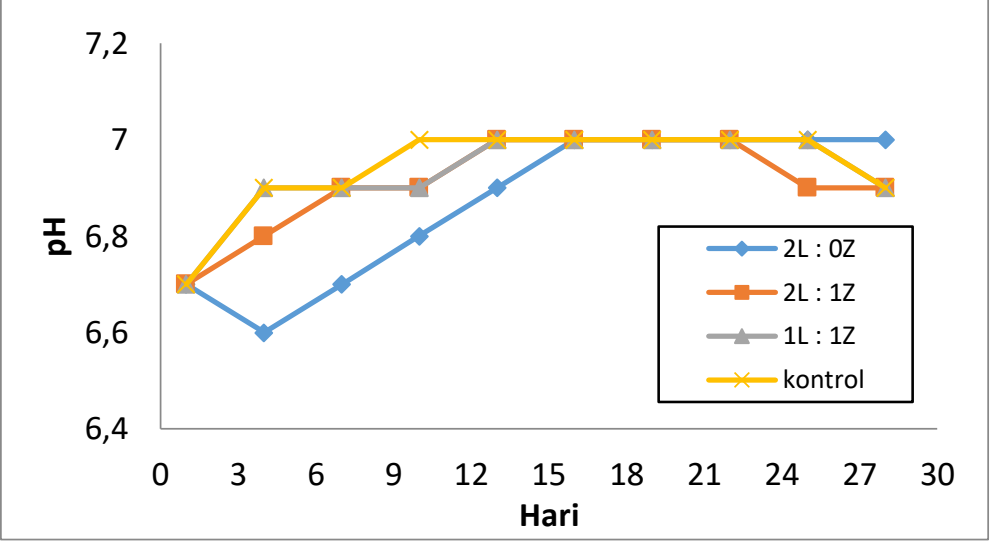

Gambar 3. Grafik Nilai pH

Secara keseluruhan dari data yang tersaji dapat diketahui bahwa selama proses berlangsung $\mathrm{pH}$ pada masing-masing reaktor tidak mengalami perubahan yang terlalu signifikan yaitu berada pada kisaran 6,6 hingga 7. Namun pada reaktor dengan penambahan lumpur PDAM sebagai media imobilisasi memilki $\mathrm{pH}$ yang cenderung lebih rendah daripada reaktor lainnya dan mengalami penurunan $\mathrm{pH}$ pada hari ke-4 namun penurunan $\mathrm{pH}$ tersebut tidak membahayakan bakteri. Hal ini dapat terjadi dikarenakan adanya akumulasi asam organik atau VFA. Volatile fatty acids (VFA) merupakan produk antara dalam produksi metana dan konsentrasinya mempengaruhi proses anaerobik. Akumulasi VFA pada reaktor tersebut dapat disebabkan oleh proses asidogenesis yang berlangsung cepat (Mellyanawaty, 2019). Dengan demikian dapat disimpulkan bahwa penambahan zeolit dan lumpur PDAM sebagai media imobilisasi memberikan efek yang baik bagi proses anaerobik karena dapat mempercepat proses penguraian bahan organik. Hal ini disebabkan oleh kandungan mineral dan logam (trace metal) seperti Fe yang terkandung dalam lumpur PDAM dapat menjadi sumber nutrisi tambahan bagi mikroorganisme. Namun peningkatan jumlah VFA dan menurunnya nilai $\mathrm{pH}$ memberikan dampak yang kurang baik karena $\mathrm{pH}$ yang rendah dapat menjadi 
inhibitor bagi pertumbuhan bakteri yang berperan dalam proses metanogenesis. Zat organik maupun anorganik baik yang terlarut maupun tersuspensi dapat menjadi penghambat ataupun racun bagi pertumbuhan mikroorganisme jika terdapat pada konsentrasi yang tinggi (Moertinah, 2010).

Dari pengamatan di atas dapat disimpulkan bahwa secara keseluruhan proses nilai $\mathrm{pH}$ pada masing-masing reaktor masih berada pada ambang batas nilai $\mathrm{pH}$ yang baik bagi proses yaitu 6-8 (Khaerunissa, 2013). Namun penambahan lumpur PDAM dalam jumlah tertentu dapat menurunkan nilai $\mathrm{pH}$, untuk itu perlu dilakukan penelitian lebih lanjut tentang ambang batas penggunaan lumpur PDAM sebagai media imobilisasi yang baik bagi proses pembentukan biogas.

\section{c. Pengamatan Produksi Biogas}

Adapun hasil pengamatan volume biogas yang terbentuk dapat dilihat pada Gambar 4. berikut :

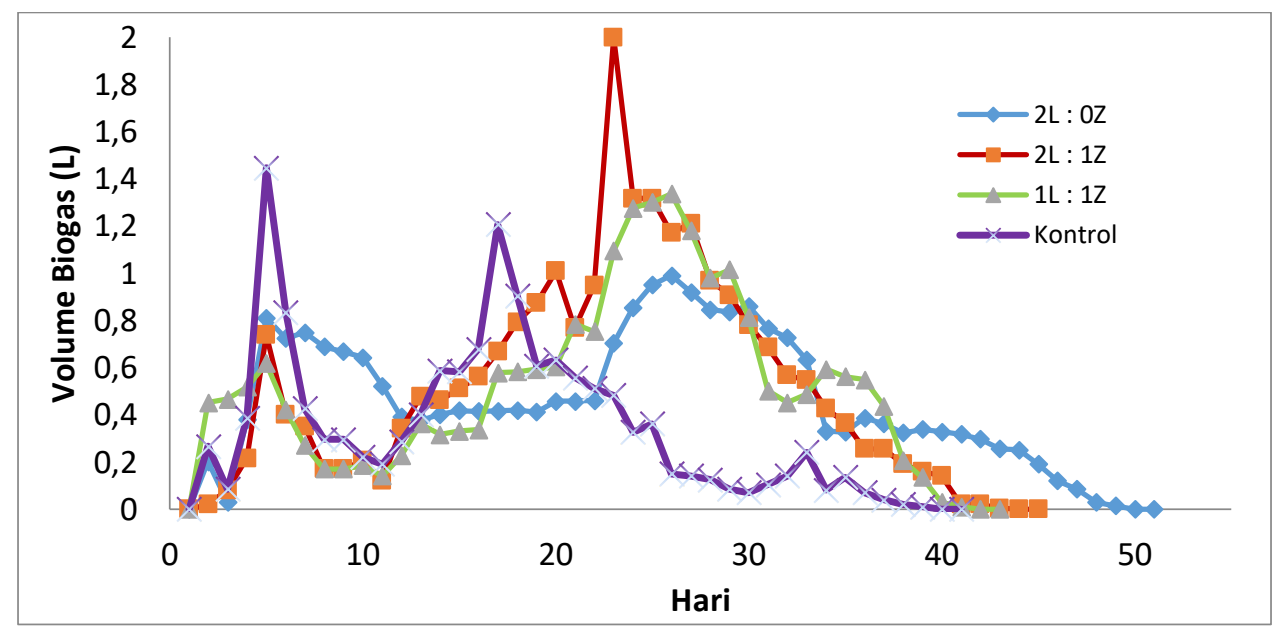

Gambar 4. Grafik Volume Biogas

Pada rentang hari ke- 1-4 reaktor yang berperan sebagai reaktor kontrol memiliki hasil produksi biogas yang cenderung lebih tinggi dari reaktor lainnya. Hal tersebut terjadi karena pada tahap ini bakteri pada reaktor kontrol hanya berfokus pada produksi biogas saja, sedangkan pada reaktor yang menggunakan media imobilisasi bakteri masih beradaptasi dan membentuk lapisan biofilm pada media, setelah biofilm terbentuk bakteri akan melanjutkan proses fermentasi yang lebih baik. Namun, setelah hari ke-6 produksi biogas pada reaktor dengan penambahan media A (2:0) menghasilkan biogas yang paling tinggi.

Fase kematian bakteri ditunjukan oleh penurunan produksi biogas yang terjadi pada hari ke-19 pada reaktor D, hari ke-27 pada reaktor B, dan hari ke-28 pada reaktor A dan $\mathrm{C}$ hingga tidak dapat menghasilkan biogas lagi yang menandakan semua bakteri didalam reaktor telah mati. Adapun volume total gas yang dihasilkan serta waktu tinggal untuk masing-masing reaktor dapat dilihat pada tabel berikut :

Tabel 1. Volume Total Gas yang Dihasilkan

\begin{tabular}{lcl}
\hline Reaktor & Volume Total Gas yang Dihasilkan & Waktu Tinggal \\
\hline A (2L:0Z) & 23,0953 liter & 51 hari \\
B (2L:1Z) & 23,2844 liter & 46 hari \\
C (1L:1Z) & 21,8447 liter & 45 hari \\
D (kontrol) & 13,9293 liter & 42 hari \\
\hline
\end{tabular}


Dari tabel tersebut diketahui bahwa akumulasi biogas yang dihasilkan reaktor B paling banyak daripada reaktor lainnya yaitu sebesar 23,2844 L sedangkan reaktor D memiliki akumulasi biogas yang paling sedikit yaitu sebesar 13,9293 L. Rentang waktu proses produksi biogas tersebut juga berbeda-beda pada masing-masing reaktor yaitu 51 hari untuk reaktor A, 46 hari untuk reaktor B, 45 hari untuk reaktor C, serta 42 hari untuk reaktor D. Media imobilisasi dapat memperpanjang masa produktif sistem karena terbentuknya biofilm. Mikroorganisme memerlukan trace metal dan vitamin untuk menjalankan fungsinya. Keberadaan trace metal di dalam metabolisme mikroorganisme diyakini dapat meningkatkan laju produksi biogas. Trace metal yang paling berpengaruh meliputi nikel (Ni), kobalt (Co) dan besi (Fe) (Suryana, 2012). Berdasarkan penelitian yang telah dilakukan oleh Lasah (2012), diketahui bahwa kandungan terbesar dari lumpur PDAM Tirta Khatulistiwa Pontianak adalah besi sebesar 53,38\%. Oleh karena itu penggunaan lumpur PDAM sebagai media imobilisasi dapat meningkatkan produksi biogas.

Reaktor A dengan penambahan media imobilisasi berupa lumpur PDAM dan zeolit dengan perbandigan (2:0) memberikan hasil produksi biogas yang tinggi, namun tidak lebih tinggi daripada reaktor $\mathrm{B}$ dengan perbandingan $(2: 1)$ hal tersebut diduga karena konsentrasi logam-logam atau trace metal seperti Fe yang terdapat didalam reaktor A terlalu tinggi menyebabkan trace metal tersebut menjadi bersifat racun bagi mikroorganisme, sehingga produksi biogas menjadi kurang optimal. Kandungan Fe pada proses fermentasi yang terlalu tinggi dapat menjadi racun bagi proses metabolisme mikroba dan menyebabkan perombakan kandungan organik pada limbah berkurang (Suryana, 2012). Reaktor B dengan penambahan lumpur PDAM dan zeolit dengan perbandingan 2:1 memberikan hasil produksi gas paling baik, hal tersebut berarti bahwa perbandingan (2:1) merupakan perbandingan yang paling optimal. Pada reaktor $\mathrm{C}$ dengan perbandingan antara lumpur PDAM dan zeolit (1:1) memberikan hasil yang tidak lebih baik daipada reaktor A dan B, hal tersebut diduga karena pada reaktor ini kandungan logam dan mineral yang terdapat dalam media imobilisasi masih belum mencukupi untuk kebutuhan mikroorganisme sehingga produksi biogas kurang optimum. Sedangkan pada reaktor D yang merupakan reaktor tanpa penambahan media imobilisasi dan berperan sebagai reaktor kontrol ternyata memiliki hasil biogas yang paling sedikit dengan waktu tinggal yang paling singkat pula. Hal tersebut terjadi karena pada reaktor tidak memiliki media imobilisasi yang berperan sebagai tempat tinggal serta sumber energi tambahan bagi bakteri. Sehingga bakteri di dalam reaktor tersebut wash out dan tidak mendapatkan sumber nutrisi tambahan seperti reaktor lainnya yang menyebabkan biogas yang dihasilkan lebih sedikit pula. Variasi komposisi terbaik untuk produksi biogas adalah perbandingan lumpur PDAM dan zeolit sebesar (2:1). Ditunjukan dengan hasil produksi biogas pada reaktor B yaitu sebanyak 23,2844 liter dengan waktu proses selama 46 hari.

\section{d. Pengamatan Konsetrasi Metana $\left(\mathrm{CH}_{4}\right)$}

Hasil pengamatan konsentrasi $\mathrm{CH}_{4}$ dapat dilihat pada Gambar 5 dan Tabel 2. Dari tabel tersebut diketahui bahwa reaktor yang memiliki hasil konsentrasi $\mathrm{CH}_{4}$ paling tinggi adalah reaktor $\mathrm{B}$, dimana media yang digunakan adalah campuran antara lumpur PDAM dan zeolit dengan perbandingan 2:1. Hal tersebut menunjukan bahwa penambahan campuran antara lumpur PDAM dan zeolit sebagai media imobilisasi memberikan pengaruh positif terhadap peningkatan konsentrasi $\mathrm{CH}_{4}$ yang dihasilkan, karena media imobilisasi tersebut dapat berperan sebagai sumber trace metal dan mineral yang dibutuhkan sebagai sumber nutrisi bagi mikroorganisme. 


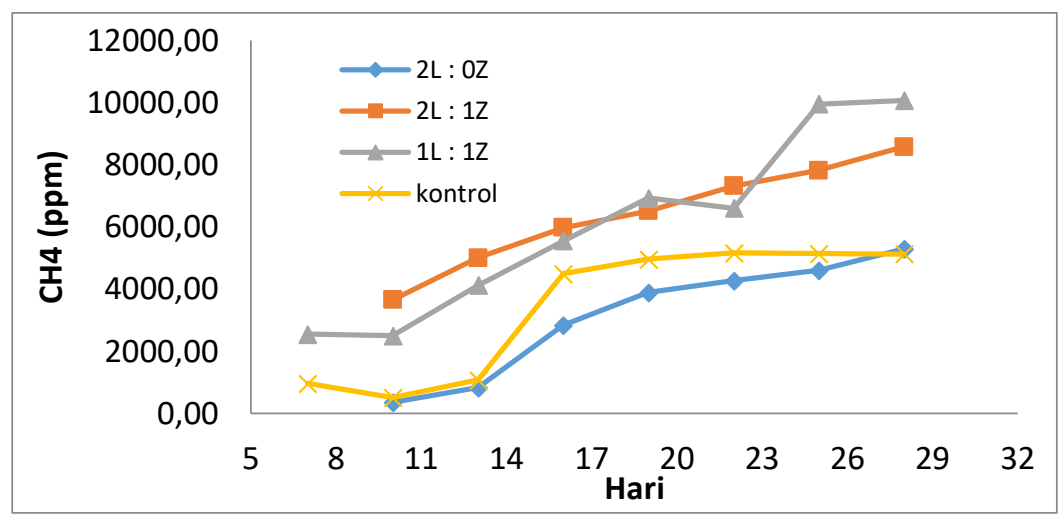

Gambar 5. Grafik Konsentrasi $\mathrm{CH}_{4}$

Konsentrasi $\mathrm{CH}_{4}$ cenderung terus mengalami peningkatan seiring dengan bertambahnya waktu. Adapun konsentrasi $\mathrm{CH}_{4}$ dapat dilihat pada tabel berikut:

Tabel 2. Konsentrasi $\mathrm{CH}_{4}$

\begin{tabular}{lllllll}
\hline Hari & $\begin{array}{l}\text { Reaktor } \\
(2 \mathrm{~L}: 0 \mathrm{Z}) \\
(\mathrm{ppm})\end{array}$ & $\begin{array}{l}\text { A }) \\
7\end{array}$ & $\begin{array}{l}\text { Reaktor } \\
(2 \mathrm{~L}: 1 \mathrm{Z}) \\
(\mathrm{ppm})\end{array}$ & $\begin{array}{l}\text { Beaktor } \\
(1 \mathrm{~L}: 1 \mathrm{Z}) \\
(\mathrm{ppm})\end{array}$ & $\begin{array}{l}\mathrm{C}) \\
\begin{array}{l}\text { Reaktor } \\
(\text { kontrol }) \\
(\mathrm{ppm})\end{array}\end{array}$ & $\mathrm{D}$ \\
\hline 10 & 360,36 & $3.656,40$ & $2.551,15$ & 962,42 \\
13 & 825,72 & $5.008,10$ & $4.127,80$ & 509,69 \\
16 & $2.840,46$ & $5.982,02$ & $5.547,09$ & $1.077,51$ \\
19 & $3.886,27$ & $6.518,04$ & $6.924,30$ & $4.965,40$ \\
22 & $4.272,65$ & $7.319,65$ & $6.600,76$ & $5.166,48$ \\
25 & $4.607,67$ & $7.817,27$ & $9.957,68$ & $5.138,18$ \\
28 & $5.292,65$ & $8.581,68$ & $10.068,26$ & $5.130,83$ & \\
\hline
\end{tabular}

Pada reaktor A, media yang digunakan berupa lumpur PDAM tanpa campuran zeolit menghasilkan biogas dengan konsentrasi $\mathrm{CH}_{4}$ paling rendah hal tersebut menunjukan bahwa penggunaan lumpur PDAM sebagai media imobilisasi tidak memberikan pengaruh yang baik. Lumpur PDAM yang digunakan berperan sebagai sumber trace metal seperti Fe dan nutrisi tambahan yang diperlukan bagi mikroorganisme, namun pada reaktor ini diduga konsentrasi trace metal tersebut berlebih sehingga menurunkan konsntrasi $\mathrm{CH}_{4}$ yang dihasilkan. Trace metal mempunyai peran yang penting dalam pertumbuhan bakteri metanasi dan pembentukan metana. Namun trace metal konsentrasi tinggi mempunyai beberapa pengaruh racun terhadap bioematanasi (Narayana,dkk, 2010). Jika dilihat dari jumlah biogas yang dihasilkan reaktor A merupakan reaktor dengan akumulasi biogas terbanyak, namun dengan konsentrasi $\mathrm{CH}_{4}$ rendah. Pada reaktor A diduga biogas yang dihasikan memiliki campuran gas lainnya seperti $\mathrm{CO}_{2}$ dengan konsentrasi tinggi, hal tersebut karena $\mathrm{pH}$ pada reaktor A cenderung lebih rendah dari reaktor lainnya. Nilai $\mathrm{pH}$ yang rendah menunjukan bahwa yang terjadi adalah proses asidogenesis yang menghasilkan VFA dan $\mathrm{CO}_{2}$ sehingga suasana reaktor jadi lebih asam, kondisi asam tersebut menyebabkan pertumbuhan bakteri metanogen menjadi terhambat sehingga berpengaruh pada konsentrasi $\mathrm{CH}_{4}$ yang dihasilkan (Khaerunnisa, 2013). Hal tersebut juga didukung dengan penelitian yang telah dilakukan Suraya (2012) bahwa produksi gas $\mathrm{CH}_{4}$ cenderung mengalami penurunan seiring meningkatnya jumlah $\mathrm{Fe}$ dalam fermentasi, maka dapat dikaitkan dengan menurunnya gas $\mathrm{CH}_{4}$ mengakibatkan meningkatnya gas $\mathrm{CO}_{2}$ yang diproduksi selama proses fermentasi. Oleh sebab itu, hubungan gas $\mathrm{CO}_{2}$ yang 
dihasilkan selama proses fermentasi berbanding terbalik dengan gas $\mathrm{CH}_{4}$. Meski demikian pada hari ke-28 konsentrasi $\mathrm{CH}_{4}$ pada reaktor A lebih tinggi dari pada reaktor $\mathrm{D}$, hal tersebut menunjukan bahwa reaktor dengan penambahan media imobilisasi berupa lumpur PDAM lebih baik daripada reaktor kontrol tanpa penambahan media imobilisasi, namun membutuhkan waktu yang lebih lama sehingga kurang efektif.

Penambahan zeolit dan lumpur PDAM sebagai media imobilisasi juga mempengaruhi hasil produksi $\mathrm{CH}_{4}$ hal tersebut dapat terjadi karena zeolit merupakan media berpori yang dapat menjadi tempat melekatnya bakteri dan dapat memperluas permukaan media. Sedangakn lumpur PDAM dapat menjadi sumber mikronutrien bagi bakteri. Hal tersebut juga telah dipaparkan oleh Halim, dkk (2015) bahwa penggunaan zeolit sebagai media imobilisasi memberikan peningkatan pada laju pertumbuhan bakteri, selain itu juga terjadi peningkatan laju pembentukan metana hingga $50 \%$ pada proses produksi biogas. Berdasarkan Tabel 5.2 diketahui bahwa konsentrasi $\mathrm{CH}_{4}$ terbesar didapat sebesar $10.068 \mathrm{ppm}$, jika dibandingkan dengan proses pembuatan biogas tanpa adanya penambahan media imobilisasi maka hasil konsentrasi metana tersebut jauh lebih besar. Seperti yang telah dilakukan Ivontianti (2019), pada penelitian ini didapatkan konsentrasi CH4 maksimal sebesar 5.133 ppm. Sedangkan penelitian yang dilakukan Sara (2019) menunjukan bahwa konsentrasi CH4 yang didapat sebesar $7.634 \mathrm{ppm}$.

Dari data yang tersaji pada Tabel 5.2 diketahui bahwa $\mathrm{CH}_{4}$ yang dihasilkan semakin meningkat berbanding lurus dengan perbandingan jumlah lumpur PDAM yang digunakan sebagai media imobilisasi. Namun pada penambahan lumpur PDAM dengan perbandingan paling besar yaitu 2:0 menunjukan hasil penurunan konsenrasi $\mathrm{CH}_{4}$ yang sangat signifikan. Penurunan tersebut dapat disebabkan karena kandungan Fe yang berasal dari lumpur PDAM pada proses fermentasi sudah cukup tinggi sehingga berpengaruh terhadap proses bioemtanasi dan menyebabkan penurunan laju perombakan kandungan organik menjadi biogas. Penambahan media imobilisasi berupa lumpur PDAM memberikan pengaruh positif terutama pada perbandingan komposisi antara lumpur PDAM dan zeolit sebesar 2:1. Dengan demikian dapat disimpulkan bahwa lumpur PDAM dapat digunakan sebagai media imobilisasi pada proses produksi biogas dan memberikan pengaruh positif bagi $\mathrm{CH}_{4}$ yang dihasilkan.

\section{PENUTUP}

Berdasarkan penelitian yang telah dilakukan dapat ditarik kesimpulan bahwa penambahan lumpur PDAM dan zeolit dapat meningkatkan produksi biogas dan konsentrasi $\mathrm{CH}_{4}$ yang terkandung di dalamnya, dimana hasil yang terbaik pada variasi komposisi lumpur PDAM : zeolite 2:1.

\section{DAFTAR PUSTAKA}

Hajar, S., Wahyuni, N., Destiarti,L. 2014. "Karakterisasi Zeolit A Sintesis dari Lumpur PDAM Kota Pontianak dan Alumina". Jurnal Kimia Khatulistiwa. Vol. 3(10, Hal : 12 16, ISSN 2303-1077.

Halim, L., 2015. "Peningkatan Produksi Biogas dari Stillage dengan Imobilisasi Bakteri Anaerobik pada Media Padatan Berpori”. Thesis. Universitas Gadjah Mada : Yogyakarta.

Ivontianti, W.D., Rakasiwi, R.R., Haryati. Y., 2019, "Evaluasi Waktu Start Up pada Proses Penguraian Sampah Organik Pasar Secara Anaerobik Menggunakan Continous Stirred Tank Reactor (CSTR)". Prosiding Seminar Infrastruktur Energi Nuklir. 
Khaerunisa, G. dan Rahmawati, I. 2013. "Pengaruh pH dan Rasio COD:N Terhadap Produksi Biogas dengan Bahan Baku Limbah Industri Alkohol”. (Vinasse). Jurnal Teknologi Kimia dan Industri, Vol.2, No.3, Hal: 1-7.

Lasah, Y. 2012. "Kemampuan Multi Soil Layering dari Lumpur PDAM dan Abu

Sekam Padi untuk Mengolah Limbah Fosfat dan Amonia Buatan”. Skripsi. FMIPA Universitas Tanjungpura : Pontianak.

Mellyanawati, D., Purnomo, C.W., Budhijanto, W., 2017."Pengaruh Penambahan Zeolit Alam Termodifikasi sebagai Media Imobilisasi Bakteri terhadap Dekomposisi Material Organik secara Anaerob”.Jurnal Rekayasa Proses, Vol. 11 No.1 Hal: 36-42.

Moertinah, Sri. 2010. "Kajian Proses Anaerobik Sebagai Alternatif Teknologi Pengolahan Air Limbah Industri Organik Tinggi”. Jurnal Riset Teknologi Pencegahan Pencemaran Industri. Vol 1. No.2. Hal : 104-114.

Sara, Y.V,. 2019.'Evaluasi Pengaruh Pengadukan Terhadap Proses Produksi Biogas dari Sampah Organik Pasar Flamboyan Pontianak". Tugas Akhir Penelitian. Teknik Kimia. Universitas Tanjungpura.

Suraya, I. Tiarasti, H. Irvan. Trisakti, B. 2012. "Pengaruh Kadar Fe Terhadap Kuantitas Biogas yang Dihasilkan dari Fermentasi Limbah Cair KelapaSawit". Jurnal Teknik Kimia USU, Vol. 1, No. 1

Ziemiński, K. \& Frąc, M., 2012."Methane fermentation process as anaerobic digestion of biomass: Transformations, stages and microorganisms". African Journal of Biotechnology, 11(18), pp.4127-4139. 